\title{
Influence of photoperiod on differentiation of male cells in Helix aspersa. An autoradiographic study
}

\author{
A. MEDINA $\left({ }^{1}\right)$, Bernadette GRIFFOND $\left({ }^{2}\right)$, P. GOMOT $\left({ }^{2}\right)$
}

(1) Departamento de Biologia Celular, Facultad de Biologia, 41012 Sevilla, Spain.

$\left({ }^{2}\right)$ Laboratoire de Zoologie et Embryologie, UA CNRS N 040687. 25030 Besancon Cedex, France.

Summary. Hibernating snails (Helix aspersa) were activated by placing them in environmental chambers under either long-day (LD 18:6) or short-day (LD $8: 16$ ) lighting conditions. One day after activation all the snails were injected with $\left({ }^{3} \mathrm{H}\right)$ thymidine $(5 \mu \mathrm{Ci} / \mathrm{g}$ wet weight) in order to estimate the duration of spermatogenic phases under long and short-day cycles. Our histological and autoradiographic observations show that long-day cycles have a positive influence on the development of the male cell line, which becomes apparent from the third week of exposure. While in long-day snails labeled spermatozoa were identifiable 28 days after $\left({ }^{3} \mathrm{H}\right)$-thymidine injection, in short-day snails neither labeled spermatozoa nor spermatids were present in the gonads of animals killed as late as 39 days post-injection. These data strongly suggest that the photoperiod, besides acting on spermatogonial proliferation (Sokolove et al., 1983; Gomot and Griffond, 1987), has an important effect on the second meiotic division. In the course of spermatogenesis in Helix aspersa, the step from secondary spermatocyte to spermatid is probably the most sensitive to environmental factors.

\section{Introduction.}

Photoperiod is one of the environmental factors involved in regulation of reproductive activity in pulmonate gastropods (see Gomot and Deray, 1987). Lengthy photophases have been demonstrated to favor the development of male gametogenesis in the slugs, Deroceras reticulatum (Henderson and Pelluet, 1960) and Limax maximus (Sokolove and McCrone, 1978; McCrone and Sokolove, 1979), as well as in the snail, Helix aspersa (Gomot and Gomot, 1985 ; Gomot and Griffond, 1987). In these species the influence of the photoperiod on spermatogenesis has been studied several weeks after exposure to different lighting cycles, and consequently the immediate effects of the photoperiod on 
differentiation of the various male cell types are still unknown. The aim of the present study was to examine the evolution of spermatogenesis in snails exposed to long- and short-day cycles and to determine at what step of spermatogenesis the photoperiod would act.

\section{Material and methods.}

Animals. - Adult snails (Helix aspersa) were taken from a stock of hibernating animals maintained at $7{ }^{\circ} \mathrm{C}$ in the « Centre Universitaire d'Héliciculture » ( 1 ). After a short hibernation ( 82 days), the snails were placed in plastic boxes in environmental chambers under either long-day (LD 18:6) or short-day (LD $8: 16)$ lighting conditions. Both groups of animals were kept at constant temperature $\left(20^{\circ} \mathrm{C}\right)$ and humidity $(\mathrm{rh}=95 \%)$ and fed an artificial mixture prepared by the UCAAB ( ${ }^{2}$ ).

Radioactive labeling. - Twenty-four hours later, all the snails were injected in the general body cavity with $0.2 \mathrm{ml}$ of tritiated thymidine ( $\simeq 5 \mu \mathrm{Ci} / \mathrm{g}$ wet weight). The thymidine (methyl- ${ }^{3} \mathrm{H}$; specific activity: $1 \mathrm{Ci} / \mathrm{mM}$ ) was supplied by the CEA $\left.{ }^{3}\right)$ in bottles containing $1 \mathrm{mCi}$ in $1 \mathrm{ml}$ of sterile water. Before thymidine injection the content of each bottle was diluted in $3 \mathrm{ml}$ of Ringer's solution.

Removal and treatments of gonads. - One day after radioactive labeling the gonads of two long-day and two short-day injected snails were removed and placed in $3 \mathrm{mM}$ non-radioactive thymidine in Ringer's solution for $40 \mathrm{~min}$ to dilute the $\left({ }^{3} \mathrm{H}\right)$-thymidine that had not been incorporated into DNA. The tissue was fixed in $2 \%$ glutaraldehyde in $0.1 \mathrm{M}$ cacodylate buffer $(\mathrm{pH} 7.3)$, postfixed in osmium tetroxide, dehydrated through an ethanol series and then embedded in resin (Spurr, 1969). This operation was repeated 4, 7, 11, 14, 18, 21, 25, 26, 28, 32,35 and 39 days after injection.

The sections used for autoradiographic study ( $2 \mu \mathrm{m}$ thick) were coated with photographic emulsion Ilford type L4. After exposure for 15 or 21 days at $5{ }^{\circ} \mathrm{C}$, they were processed with D19 developer for $4 \mathrm{~min}$ at $25^{\circ} \mathrm{C}$ (Simonnet et al., 1976) and fixed with $30 \%$ sodium hyposulfite. Some of these sections were slightly stained with toluidine blue and others were examined without staining.

\section{Results.}

Long-day snails (table 1). One day after radioactive injection, clusters of spermatogonia (fig. 1) and early primary spermatocytes were clearly labeled. Four days after exposure to $\left({ }^{3} \mathrm{H}\right)$-thymidine, labeled zygotene and pachytene sperma-

(1) Centre Universitaire d'Héliciculture, 5, rue Ronchaux, 25000 Besançon, France. France.

$\left({ }^{2}\right)$ Union des Coopératives Agricoles d'Aliment du Bétail, Chierry, 02400 Château-Thierry,

$\left({ }^{3}\right)$ Commissariat à l'Energie Atomique, 91191 Gif-sur-Yvette, France. 
tocytes were present in the gonadal acini (fig. 2). Secondary spermatocytes were the most mature cells to show the radioactive label 11 days after injection (fig. 3 ). Labeled early and mid-spermatids were observed 25 and 26 days post-injection, respectively (fig. 4). Finally, late spermatids and morphologically mature spermatozoa were labeled 28 days after the $\left({ }^{3} \mathrm{H}\right)$-thymidine injection (figs. 5,6 ).

TABLE 1

Successive appearance of label in the various male cell types in both experimental groups. Whereas labeled early spermatids are present 25 days after injection and spermiogenesis is achieved within three days under long-day conditions, no labeled spermatids were found at any time under short-day conditions.

\begin{tabular}{lcc}
\hline & Long-day snails & Short-day snails \\
\hline Spermatogonia & 1st day & 1st day \\
\hline Primary spermatocytes & & \\
- early spermatocytes & $\begin{array}{l}\text { 1st day } \\
\text { - zygotene spermatocytes }\end{array}$ & $\begin{array}{l}\text { 4th day } \\
\text { 4th day }\end{array}$ \\
- pachytene spermatocytes & 11th day & 4th day \\
\hline Secondary spermatocytes & 25th day & 14th day \\
\hline Early spermatids & 26th day & - \\
\hline Mid spermatids & 28th day & - \\
\hline Late spermatids/ & & - \\
spermatozoa & & \\
\hline
\end{tabular}

Short-day snails (table 1). - Up to the secondary spermatocyte phase the duration of spermatogenic stages was comparable to that described above for long-day snails. However, in short-day snails no labeled spermatids or spermatozoa were found at any time during the present experiment.

\section{Discussion and conclusions.}

Duration of spermatogenic stages. - According to the autoradiographic study, the minimum time required for a snail primary spermatocyte in the phase of pre-meiotic DNA synthesis to differentiate into a mature spermatozoon was about 28 days under long-day conditions. The primary spermatocyte stage lasted between 7 to 10 days and the secondary spermatocyte took from 10 to 14 days to become a spermatid, whereas spermiogenesis was a phase of short duration ( 3 to 6 days). In general, these data agree with those reported by Bloch and Hew (1960) in snails (Helix aspersa) bred without special environmental conditions, 


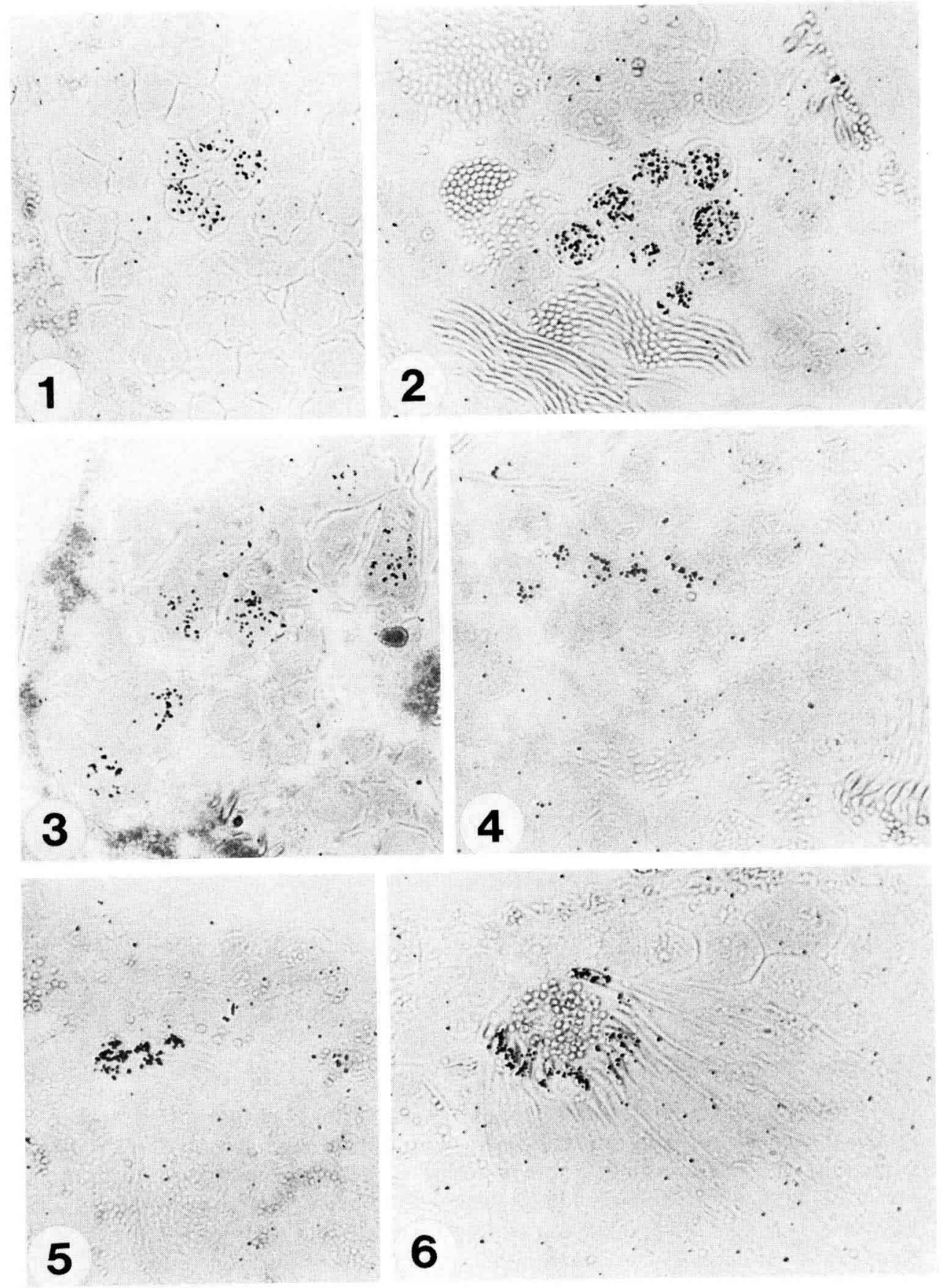


though there are some differences between the two estimates. Spermatogenesis in the opisthobranch, Phyllaplysia taylori is noticeably faster; a primary spermatocyte requires only 10 days to become a spermatozoon (Beeman, 1970a) which leaves the gonad 4 days later (Beeman, 1970b). Kelley et al. (1982) estimate that spermatogenesis in the mussel, Mytilus californianus, lasts a similar time.

Influence of photoperiod on the development of the male cell line. - Several experimental studies have shown that long photoperiods stimulate the reproductive capacity of pulmonate gastropods (Énée et al., 1982 ; Laurent et al., 1984 ; Gomot and Gomot, 1985), affecting both ovopository activity (Bohlken and Joosse, 1982 ; Énée et al., 1982 ; Joosse, 1984 ; Bohlken et al., 1986) and spermatogenesis (Henderson and Pelluet, 1960 ; Sokolove and McCrone, 1978 ; McCrone and Sokolove, 1979, 1986 ; McCrone et al., 1981 ; Melrose et al., 1983 ; Sokolove et al., 1983, 1984 ; Gomot and Gomot, 1985; Gomot and Griffond, 1987). However, in Cepaea nemoralis neither gametogenesis nor reproductive capacity appears to be influenced by photoperiod (Hunter and Stone, 1986).

The results of the present study show that long photoperiods have a positive effect on Helix aspersa spermatogenesis from the third week of exposure to long-day cycles.

In long-day snails, labeled early spermatids appeared 25 days after $\left({ }^{3} \mathrm{H}\right)$ thymidine injection; labeled spermatozoa were found in snails killed 28 days post-injection. In contrast, within 39 days, labeled spermatids and spermatozoa were still absent in short-day animals. Thus, it is evident that the delay observed in the spermatogenic process of pulmonates maintained under short-day is not only due to less spermatogonial proliferation, as reported previously (Sokolove $e t$ al., 1983; Gomot and Griffond, 1987), but also to a lengthening of the late spermatogenesis affecting the second meiotic division. Indeed, there does not appear to be a blockade at this level of spermatogenesis similar to that occurring at low temperatures (Gomot et al., 1986), since spermatozoa are formed some weeks later (Gomot and Griffond, 1987). However, our observations and previous data (Gomot et al., 1986) do suggest that, in the course of spermatogenesis, the step from secondary spermatocyte to spermatid is the most sensitive to environmental factors. Subsequent studies are required to ascertain whether spermiogenesis is also delayed significantly under short-day conditions.

Autoradiographic micrographs of non-stained gonadal sections exposed to photographic emulsion for 15 days. All the pictures correspond to long-day snails.

FIG. 1. - Cluster of labeled spermatogonia 1 day after injection. The larger neighboring cells are primary spermatocytes that have not been labeled $(\times 620)$.

FIG. 2. - Labeled zygotene spermatocytes 4 days after injection $(\times 620)$.

FIG. 3. - Secondary spermatocytes showing radioactive label. The silver grains are less abundant and more scattered throughout the nuclei $(\times 620)$.

FIG. 4. - Isogenic group of labeled early spermatids after 25 days of exposure to $\left({ }^{3} \mathrm{H}\right)$-thymidine $(\times 620)$.

FIG. 5. - Late spermatids displaying well labeled nuclei. Their axonemes are recognizable. Snail sacrificed 28 days after injection $(\times 620)$.

FIG. 6. - Bundle of spermatozoa showing silver grains on their nuclei after an exposure of 28 days to $\left({ }^{3} \mathrm{H}\right)$-thymidine. The sperm heads are embedded in the cytoplasm of a Sertoli cell, in which numerous lipid droplets are distinguished $(\times 620)$. 
In the slug, Limax maximus, the increased spermatogonial DNA synthesis observed in long-day animals results from the induction of the release from cerebral cells of one or more gonadotropic factors that act on the male cell line (McCrone et al., 1981; Melrose et al., 1983; Sokolove et al., 1983, 1984 ; McCrone and Sokolove, 1986). According to Sokolove et al. (1983), 3 to 4 weeks of exposure to long-day cycles is needed to promote the release of such a factor(s). This finding is consistent with our observations since in long-day snails spermiogenesis is active at the end of the third week, whereas in short-day snails the gonad remains quite inactive. Very likely, in Helix there is neuroendocrine control of spermatogenesis comparable to that found in Limax, though other experimental tests must be carried out to demonstrate this hypothesis. If such a neuroendocrine control exists, the factor(s) involved would act not only on spermatogonial proliferation, but also on the division of secondary spermatocytes and possibly on spermiogenesis as well.

Reçu en juin 1987

Accepté en février 1988.

Acknowledgements. - The inestimable technical assistance of Ms. V. Gire, Mrs. R. Garcia and Mr. F. Sanchez is greatly appreciated.

Résumé. Influence de la photopériode sur la différenciation des cellules mâles dans l'ovotestis d'Helix aspersa: Etude autoradiographique.

Après 82 jours d'hibernation, des escargots adultes Helix aspersa ont été remis en activité et soumis soit à une photopériode longue (18 h lumière : $6 \mathrm{~h}$ obscurité) soit à une photopériode courte ( $8 \mathrm{~h}$ lumière : $16 \mathrm{~h}$ obscurité). Un jour après le réveil, tous les animaux ont reçu une injection de $\left({ }^{3} \mathrm{H}\right)$-thymidine $(5 \mu \mathrm{Ci} / \mathrm{g}$ de poids frais) afin d'estimer la durée des différentes étapes de la spermatogenèse dans les deux conditions d'éclairement journalier. Nos observations histologiques et autoradiographiques démontrent une influence positive des cycles d'éclairement longs, qui se manifeste à partir de la troisième semaine. Alors que chez les escargots de jours longs des spermatozoïdes marqués sont identifiés 28 jours après l'injection de thymidine, chez les escargots de jours courts ni spermatides ni spermatozoïdes marqués n'apparaissent pendant toute la durée de l'expérience (39 jours). Ces résultats suggèrent que la photopériode, en plus d'une action sur la prolifération spermatogoniale (Sokolove et al., 1983; Gomot et Griffond, 1987), exerce un effet important sur la seconde division méiotique. Au cours de la spermatogenèse d'He/ix aspersa, le passage du spermatocyte II à la spermatide apparaît être une étape délicate, particulièrement sensible aux facteurs d'environnement.

\section{References}

BEEMAN R. D., 1970a. An autoradiographic and phase contrast study of spermatogenesis in the anaspidean opisthobranch Phyllaplysia taylori Dall, 1900. Arch. Zool. exp. gén., 111, 5-22.

BEEMAN R. D., 1970b. An autoradiographic study of sperm exchange and storage in a sea hare, Phyllaplysia taylori, a hermaphroditic gastropod (Opisthobranchia: Anaspidea). J. exp. Zool, 175, 125-132.

BLOCH D. P., HEW H. Y. C., 1960. Schedule of spermatogenesis in the pulmonate snail Helix aspersa, with special reference to histone transition. J. biophys. biochem. Cytol., 7, 515-531. 
BOHLKEN S., JOOSSE J., 1982. The effect of photoperiod on female reproductive activity and growth of the freshwater pulmonate snail Lymnaea stagnalis kept under laboratory breeding conditions. Int. J. Invert. Reprod., 4, 213-222.

BOHLKEN S., JOOSSE J., VAN ELK R., GERAERTS W. P. M., 1986. Interaction of photoperiod and nutritive state in female reproduction of Lymnaea stagnalis. Int. J. Invert. Reprod. Dev., 10. $151-157$.

ENEE J., BONNEFOY-CLAUDET R., GOMOT L., 1982. Effet de la photopériode artificielle sur la reproduction de l'escargot Helix aspersa Müll. C.R. Acad. Sci. Paris, s. III, 294, 357-360.

GOMOT L., DERAY A., 1987. Les escargots. La Recherche, 186, 302-311.

GOMOT P., GOMOT L., 1985. Action de la photopériode sur la multiplication spermatogoniale et la reproduction de l'escargot Helix aspersa. Bull. Soc. Zool. Fr., 110, 445-459.

GOMOT P., GRIFFOND B., 1987. Répercussion de la durée d'éclairement journalier sur l'évolution des cellules nourricières et de la lignée mâle dans l'ovotestis d'He/ix aspersa. Reprod. Nutr. Dévelop., 27, 95-108.

GOMOT P., GRIFFOND B., GOMOT L., 1986. Effets de la température sur la spermatogenèse d'Escargots Helix aspersa maintenus en repos artificiel. C.R. Acad. Sci. Paris, s. III, 302, 27-32.

HENDERSON N. E., PELLUET D., 1960. The effect of visible light on the ovotestis of the slug Deroceras reticulatum (Müller). Can. J. Zool., 38, 137-178.

HUNTER R. D., STONE L. M., 1986. The effect of artificial photoperiod on growth and reproduction in the land snail Cepaea nemoralis. Int. J. Invert. Reprod. Dev. 9, 339-344.

JOOSSE J., 1984. Photoperiodicity, rhythmicity and endocrinology of reproduction in the snail Lymnaea stagnalis, 204-220. In Photoperiodic regulation of insect and mol/uscan hormones, Pitman, London (Ciba Foundation Symposium 104).

KELLEY R. N., ASHWOOD-SMITH M. J., ELLIS D. V., 1982. Duration and timing of spermatogenesis in a stock of the mussel Mytilus californianus. J. mar. biol. Ass., U.K., 62, 509-519.

LAURENT J., DERAY A., GRIMARD A.-M., 1984. Influence de la photopériode, du degré d'hétérogénéité de la population sur la dynamique de croissance et la maturation sexuelle de I'Escargot Helix aspersa. C.R. Soc. Biol., 178, $421-441$.

MCCRONE E. J., SOKOLOVE P. G., 1979. Brain-gonad axis and photoperiodically-stimulated sexual maturation in the slug, Limax maximus. J. comp. Physiol., 133, 117-123.

MCCRONE E. J., SOKOLOVE P. G., 1986. Photoperiodic activation of brains in castrates and the role of the gonad in reproductive maturation of Limax maximus. J. comp. Physiol., 158, 151-158.

MCCRONE E. J., VAN MINNEN J., SOKOLOVE P. G., 1981. Slug reproductive maturation hormone: in vivo evidence for long-day stimulation of secretion from brains and cerebral ganglia. J. comp. Physiol., 143, 311-315.

MELROSE G. R., O'NEILL M. C., SOKOLOVE P. G., 1983. Male gonadotropic factor in brain and blood of photoperiodically stimulated slugs. Gen. comp. Endocrinol., 52, 319-328.

SIMONNET G., REY-CHENNEVAZ SIMONNET F., HASSIG R., 1976. Examples of applications of radioautography for beginners with the light microscope: DNA synthesis in vivo in rat marrow, protein synthesis in vitro in reticulocytes. J. Microsc. Biol. Cell., 27, 111-114.

SOKOLOVE P. G., MCCRONE E. J., 1978. Reproductive maturation in the slug, Limax maximus, and the effects of artificial photoperiod. J. comp. Physiol., 125, 317-325.

SOKOLOVE P. G., MCCRONE E. J., VAN MINNEN J., DUNCAN W. C., 1984 . Reproductive endocrinology and photoperiodism in a terrestrial slug, 189-203. In Photoperiodic regulation of insect and molluscan hormones, Pitman, London (Ciba Foundation Symposium 104).

SOKOLOVE P. G., MELROSE G. R., GORDON T. M., O'NEILL M. C., 1983. Stimulation of spermatogonial DNA synthesis in slug gonad by a factor released from cerebral ganglia under the influence of long days. Gen. Comp. Endocrinal., 50, 95-104.

SPURR A. R., 1969. A low-viscosity epoxy resin embedding medium for electron microscopy. $J$. U/trastruct. Res., 26, $31-43$.

TRUMP B. P., SMUCKLER E. A., BENDITT E. P., 1961. A method for staining epoxy sections for light microscopy. J. U/trastruct. Res., 5, 343-345. 